\title{
Markers of Blood Cell Activation and Complement Activation in Factor VIII and von Willebrand Factor Concentrates
}

\author{
Martin F. Brodde Beate E. Kehrel \\ Experimental und Clinical Hemostasis, Department of Anesthesiology and Intensive Care, University Hospital Muenster, Germany
}

\author{
Keywords \\ Factor VIII · Hemophilia - Leukocytes · Platelets . \\ Von Willebrand factor
}

\section{Summary}

Background: Preparations of commercially available clotting factor VIII are complex protein mixtures. Most of them contain either von Willebrand factor or human serum albumin as stabilizers. The aim of the study was to quantify further proteins in twelve concentrates either of recombinant origin or derived from human plasma. Methods: Proteins were separated by two-dimensional polyacrylamide gel electrophoresis (2D-PAGE). Some proteins were quantified by ELISA. Results: Recombinant clotting factor preparations showed fewer protein spots in the 2D-PAGE, than plasma-derived preparations. Proteins identified in some of the plasma-derived concentrates included up to $90 \mathrm{ng} / \mathrm{lU}$ of the anaphylatoxin C3a, up to $40 \mathrm{ng} / \mathrm{IU}$ of the platelet $\alpha$-granule protein thrombospondin-1, up to $0.85 \mathrm{ng} / \mathrm{IU}$ of the platelet $\alpha$ granule protein platelet factor $4,3.5 \mathrm{ng} / \mathrm{IU}$ myeloperoxidase secreted by leukocytes and up to $0.05 \mathrm{ng} / \mathrm{lU}$ of the leukocyte-secreted protein $\alpha$-defensin. The protein content differed between concentrates from different manufacturers. Conclusion: The origin of the plasma used to prepare the factor concentrates might influence the protein impurities in these products. It is unknown whether the impurities observed have long-term consequences for chronic inflammatory conditions.

\author{
Schlüsselwörter \\ Gerinnungsfaktor VIII · Hämophilie · Leukozyten · \\ Thrombozyten · Von-Willebrand-Faktor
}

\section{Zusammenfassung}

Hintergrund: Gerinnungsfaktorkonzentrate zur Behandlung von angeborenen hämostaseologischen Erkrankungen sind komplexe Proteinmischungen, die oft VonWillebrand-Faktor und/oder Albumin als Stabilisatoren enthalten. Ziel dieser Untersuchungen war es, in zwölf unterschiedlichen Gerinnungsfaktorkonzentraten, die rekombinant hergestellt oder durch Fraktionierung und Reinigung aus Blutplasma gewonnen wurden, weitere Fremdproteine zu quantifizieren. Methoden: Proteine der ausgewählten Gerinnungsfaktorkonzentrate wurden durch 2D-Polyarcylamid-Gelelektrophorese aufgetrennt und mit Silber sichtbar gemacht. Einige Proteine aus je drei unterschiedlichen Produktchargen wurden über ELISA quantifiziert. Ergebnisse: Die 2D-Gelelektrophorese von rekombinant hergestellten Gerinnungsfaktorpräparaten zeigte erwartungsgemäß deutlich weniger Proteinflecken als die Analyse von Präparaten, welche aus Plasma gereinigt worden waren. In Präparaten aus Plasma fand sich bis zu $90 \mathrm{ng} / \mathrm{lE}$ des Anaphylatoxins Komplement Faktor 3a, bis zu 40 ng/IE des thrombozytären $\alpha$-Granula-Proteins Thrombospondin-1, bis zu 0,85 ng/IE Plättchen-Faktor 4, bis zu 3,5 ng/IU Myeloperoxidase und bis zu $0,05 \mathrm{ng} / \mathrm{IE} \alpha$-Defensin. Die beiden letztgenannten Proteine werden aus aktivierten Leukozyten freigesetzt. Die Präparate unterschiedlicher Hersteller unterschieden sich im Gehalt von Fremdproteinen. Schlussfolgerung: Der Ursprung des Plasmas, aus dem Gerinnungspräparate hergestellt werden, scheint die Art und Konzentration von Fremdproteinen in den Blutprodukten zu beeinflussen. Ob die Fremdproteine auf lange Sicht Einfluss nehmen auf chronisch-entzündliche Reaktionen in den behandelten Patienten, ist unbekannt.

\begin{tabular}{ll}
\hline KARGER & $($ C 2010 S. Karger GmbH, Freiburg \\
$\begin{array}{l}\text { Fax }+497614520714 \\
\text { Information@Karger.de } \\
\text { www.karger.com }\end{array}$ & $\begin{array}{l}\text { Accessible online at: } \\
\text { www.karger.com/tmh }\end{array}$
\end{tabular}




\section{Introduction}

Hemophilia A is a severe inherited bleeding disorder caused by factor VIII (FVIII) deficiency. About 50 years ago the Swedish physicians Inga Marie Nilsson as well as Margareta and Birger Blombäck started to treat patients prophylactically with antihemophilic factors, to prevent joint damage [1], and since then the standard treatment for patients with severe hemophilia A has been clotting factor replacement therapy with FVIII concentrates.

The products used today for replacement therapy are either recombinant FVIII concentrates or concentrates derived from human plasma. Plasma for fractionation is either derived from source plasma, obtained by automated plasmapheresis, or from recovered plasma, being prepared from whole blood, mainly as a by-product of red cell production.

Hemophilia patients require treatment for their whole life, and the lifetime requirement of factor concentrates is high. In a recent study by Manco-Johnson et al. [2], the number of FVIII units administered per patient and year was approximately $6,000 \mathrm{IU} / \mathrm{kg}$ in the prophylaxis group and 2,500 IU/kg in the episodic-therapy group. Although high safety standards with regard to the potential transmission of infections have been achieved for all coagulation factor concentrates used today, in view of the huge lifetime requirement of FVIII in hemophilia A patients even small impurities may have a major health impact in such patients. Most clotting factor concentrates contain von Willebrand factor (vWF) or human serum albumin as stabilizer.

The aim of this study was to identify and quantify additional proteins, namely the neutrophil activation marker, $\alpha$ defensins (human neutrophil peptide (HNP) 1-3), myeloperoxidase, the platelet activation markers platelet factor 4 (PF-4) and thrombospondin-1 (TSP-1) and anaphylatoxin $\mathrm{C} 3 \mathrm{a}$, a product of complement activation, in twelve concentrates isolated from human plasma (eight concentrates) or made by genetically engineered cells (four concentrates).

\section{Material and Methods}

\section{Factor VIII Concentrate}

Three different batches of each of the following twelve FVIII concentrates were used:

- Immunate STIM plus ${ }^{\circledR}$ and Advate ${ }^{\circledR}$ (Baxter, Unterschleißheim, Germany),

- Helixate NexGen ${ }^{\circledR}$, Beriate $\mathrm{P}^{\circledR}$ and Haemate HS ${ }^{\circledR}$ (CSL Behring, Marburg, Germany)

- Faktor VIII SDH Intersero ${ }^{\circledR}$ (Intersero GmbH, Walluf, Germany),

- Haemoctin SDH ${ }^{\circledR}$ (Biotest AG, Dreieich, Germany),

- KOGENATE ${ }^{\circledR}$ Bayer (Bayer HealthCare AG, Leverkusen, Germany),

- ReFacto ${ }^{\circledR}$ (Wyeth Pharma GmbH, Münster, Germany),

- Fanhdi ${ }^{\circledR}$ (Grifols, Barcelona, Spain)

- Wilate ${ }^{\circledR}$ and Octanate ${ }^{\circledR}$ (Octapharma GmbH, Langenfeld, Germany)
Preparation of Concentrates

Sodium Dodecyl Sulphate-Polyacrylamide Gel Electrophoresis (SDS-PAGE)

$2 \mu \mathrm{g}$ protein from plasma-derived FVIII preparations and $10 \mu \mathrm{l}$ from recombinant FVIII preparations (1 IU) were separated using a $7.5 \%$ and a $12 \%$ SDS-PAGE under reducing conditions and visualized by silver staining according to Blum et al. [3] or blotted onto Immobiline ${ }^{\mathrm{TM}}$ sheets and detected with specific polyclonal antibodies to FVIII (Affinity Biologicals, Ancaster, ON, Canada), fibrinogen (DAKO A/S, Glostrup, Denmark), vWF (DAKO A/S) and albumin (Sigma-Aldrich, Steinheim, Germany).

\section{Separation of Proteins by Two-Dimensional Polyacrylamide Gel} Electrophoresis (2D-PAGE)

2D-PAGE, separating proteins according to charge and size was performed as described by Görg et al. [4]. $25 \mu \mathrm{g}$ protein of plasma-derived FVIII concentrates and $20 \mu \mathrm{l}$ of recombinant FVIII concentrates ( 2 IU) were dissolved in $0.5 \%$ ampholyte-containing IPG buffer matching IPG 3-10NL strips (GE Healthcare, Munich, Germany) and used for overnight rehydration of $13-\mathrm{cm}$ Immobiline ${ }^{\mathrm{TM}}$ IPG strips (GE Healthcare) with a $\mathrm{pH}$ range of 3-10NL ( $\mathrm{NL}=$ non-linear) according to the manufacturer's recommendations. Up to 12 strips were rehydrated simultaneously in $250 \mu \mathrm{l}$ rehydration solution in the Immobiline DryStrip Reswelling Cassette (GE Healthcare). Isoelectric focussing was carried out at a constant $20^{\circ} \mathrm{C}$ for a total of $12.3 \mathrm{kVh}$ on an Ettan IPGphor electrophoresis unit (GE Healthcare). Strips were equilibrated in SDS-containing buffer to prepare the sample for the second-dimension separation. The IPG strips were then placed on top of a horizontal second-dimension $7.5 \%$ polyacrylamide gel for SDS-PAGE and overlaid with $0.5 \%$ agarose in running buffer containing bromophenol blue. Electrophoresis was run at $15 \mathrm{~W} / \mathrm{gel}$ and at $4{ }^{\circ} \mathrm{C}$ until the dye front migrated to the end of the gel.

Protein spots were stained with silver to visualize them in the seconddimension gel matrix, as described elsewhere [5].

\section{Quantification of Activation Markers}

All protein quantifications were performed using ELISA according to the manufacturer's recommendations:

- neutrophil activation marker, HNP 1-3 (Hycult biotechnology b.v., Uden, the Netherlands)

- myeloperoxidase (Oxis, Beverly Hills, CA, USA)

- platelet activation markers PF-4 and TSP-1 (American Diagnostica, Pfungstadt, Germany and R and D Systems GmbH, Wiesbaden, Germany)

- anaphylatoxin C3a (Qidel, Heidelberg, Germany)

\section{Statistical Analysis}

Statistical analysis was performed using the t-test in MS Excel (Microsoft, Redmond, WA, USA) software.

\section{Results}

Clotting factor concentrates for the treatment of hemophilia A were separated by SDS-PAGE and proteins were visualized by silver staining.

All plasma-derived FVIII and vWf concentrates showed multiple protein bands in the $7.5 \%$ polyacrylamide gel (fig. 1a), and in the $12 \%$ polyacrylamide gel (fig. 1c) used to separate smaller proteins or protein fragments. All recombinant FVIII 
Fig. 1. SDS-PAGE of plasma-derived (a, c) and recombinant (b, d) coagulation factor concentrates; $2 \mu \mathrm{g}$ plasma-derived FVIII and $1 \mathrm{U}$ of recombinant FVIII per lane. a, b $7.5 \%$ polyacrylamide, $\mathbf{c}, \mathbf{d}$ $12 \%$ polyacrylamide. Reduced conditions; proteins stained with silver.

A = Immunate STIM plus; B = Faktor VIII SDH Intersero;

$\mathrm{C}=$ Haemoctin SDH;

$\mathrm{D}=$ Fanhdi $; \mathrm{E}=$

Wilate; $\mathrm{F}=$ Beriate

$\mathrm{P} ; \mathrm{G}=$ Haemate HS ;

$\mathrm{H}=$ Octanate; $\mathrm{I}=$

Advate; $\mathrm{J}=$ Helixate

NexGen; K = KO-

GENATE Bayer;

$\mathrm{L}=$ ReFacto.
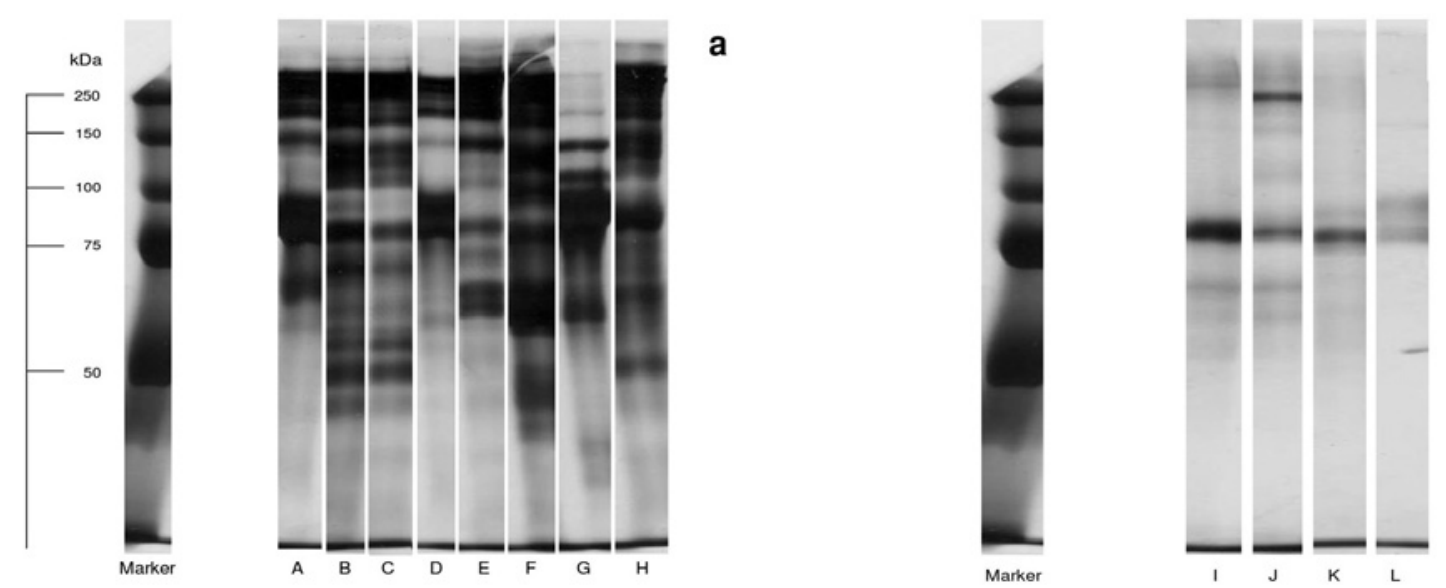

b
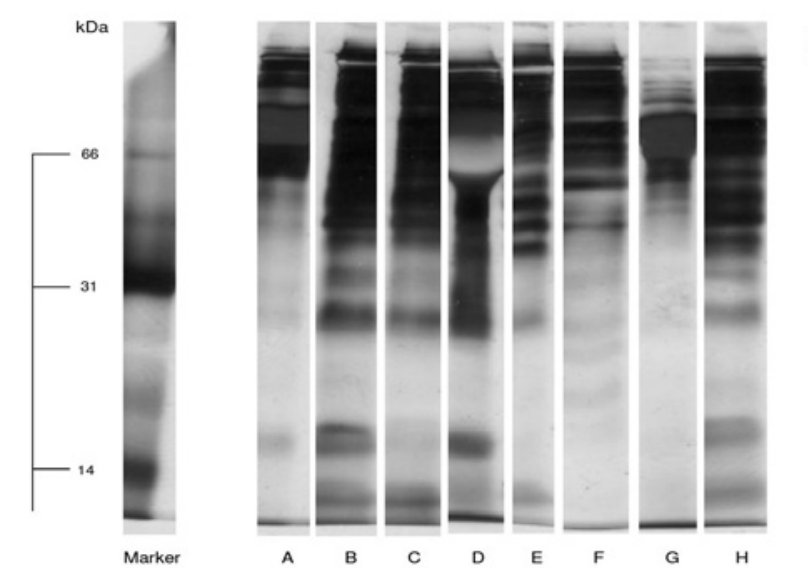

C

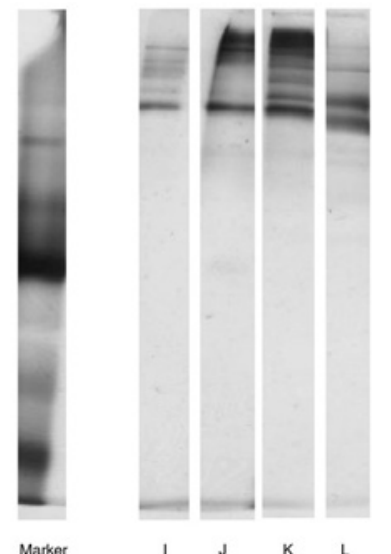

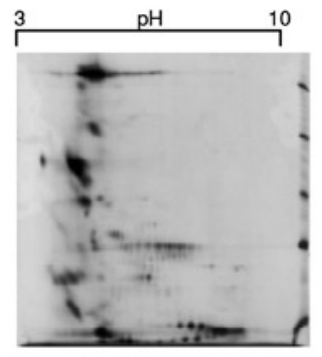

C

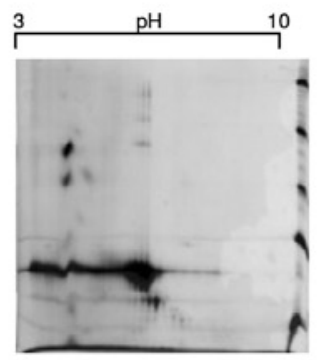

G

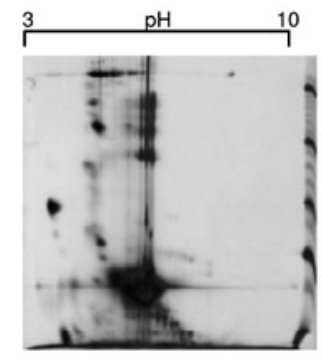

D

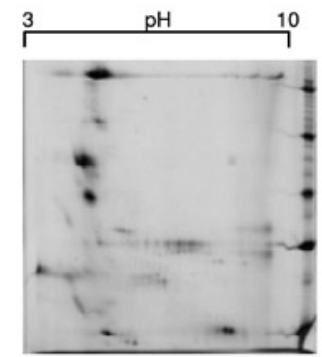

$\mathrm{H}$

Fig. 2. 2D-PAGE analysis using IPG strips $\mathrm{pH} 3-10 \mathrm{NL}$; $25 \mu \mathrm{g}$ plasma-derived FVIII concentrate per lane, $7.5 \%$ polyacrylamide; reduced conditions; proteins stained with silver.

A Immunate STIM plus; B Faktor VIII SDH Intersero; C Haemoctin SDH; D Fanhdi; E Wilate; F Beriate P; G Haemate HS; H Octanate. 

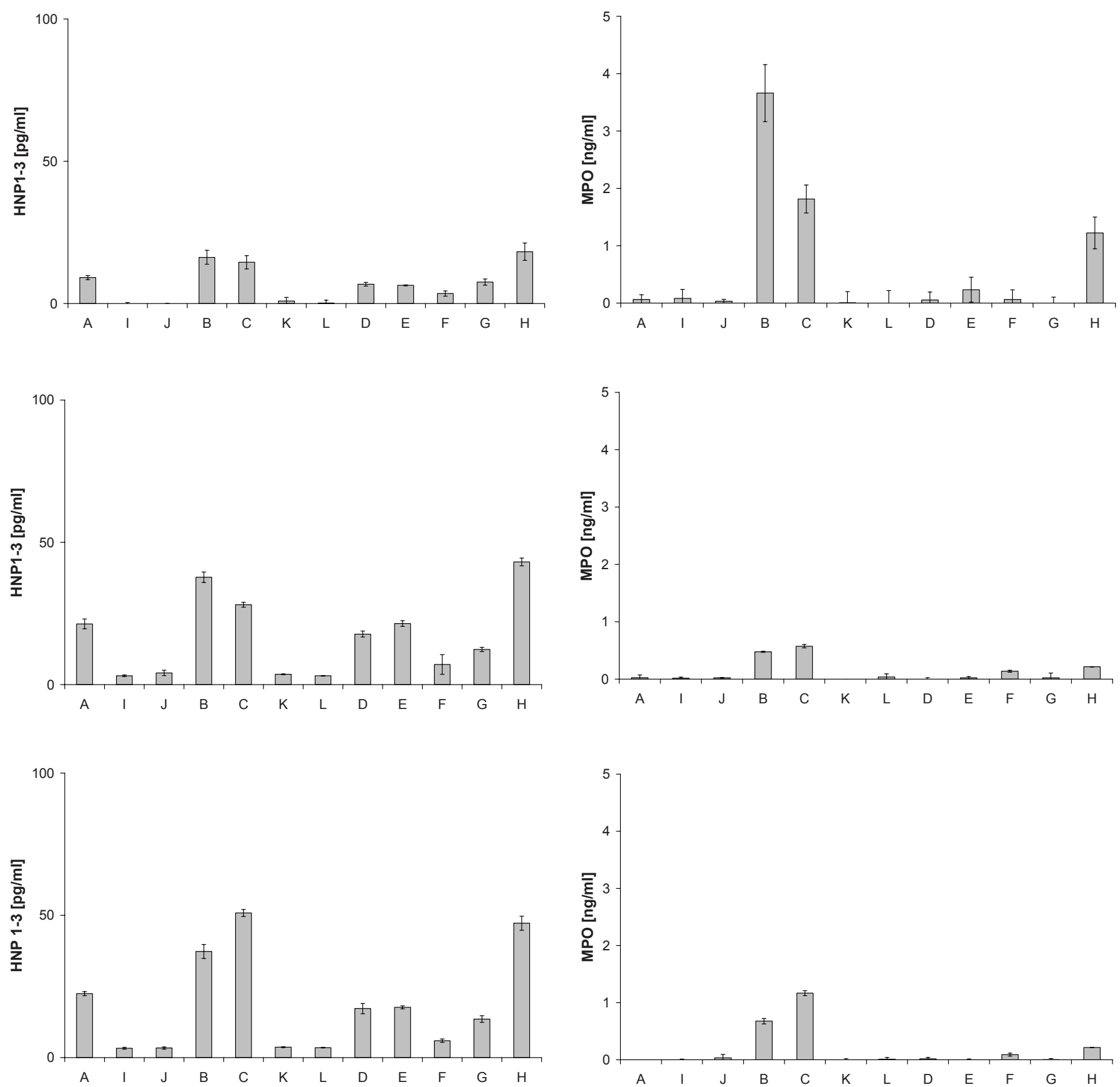

Fig. 3. HNP $1-3$ was quantified in $1 \mathrm{U}$ of FVIII concentrates using an $\alpha$-defensin(HNP 1-3)-detecting ELISA .

A: Immunate STIM plus; B: Faktor VIII SDH Intersero; C: Haemoctin SDH; D: Fanhdi; E: Wilate; F: Beriate P; G: Haemate HS; H: Octanate; I: Advate; J: Helixate NexGen; K: KOGENATE Bayer; L: ReFacto.

concentrates (fig. 1b, d) showed a major band with an apparent molecular weight of 80,000 and some minor proteins with higher apparent molecular weight. Advate showed trace bands at an apparent molecular weight of 250 and larger, which are compatible with vWf, while such bands were not seen for KOGENATE Bayer or ReFacto. None of the recombinant proteins showed proteins or polypeptides with a molecular range between 70,000 and 10,000 (fig. 1d), while the plasma-derived

Fig. 4. Myeloperoxidase was quantified in $1 \mathrm{U}$ of FVIII concentrates using an MPO-detecting ELISA .

A: Immunate STIM plus; B: Faktor VIII SDH Intersero; C: Haemoctin SDH; D: Fanhdi; E: Wilate; F: Beriate P; G: Haemate HS; H: Octanate; I: Advate; J: Helixate NexGen; K: KOGENATE Bayer; L: ReFacto.

concentrates showed several protein bands in that area (fig. 1c). As expected, prominent bands were seen for some of the plasma-derived concentrates in the molecular ranges described for human albumin and fibrinogen. All plasma-derived concentrates showed bands at the position of vWf.

To achieve better separation of proteins and polypeptides, the concentrates were analyzed using 2D-PAGE with isoelectric focussing in the first dimension using nonlinear IPG strips 

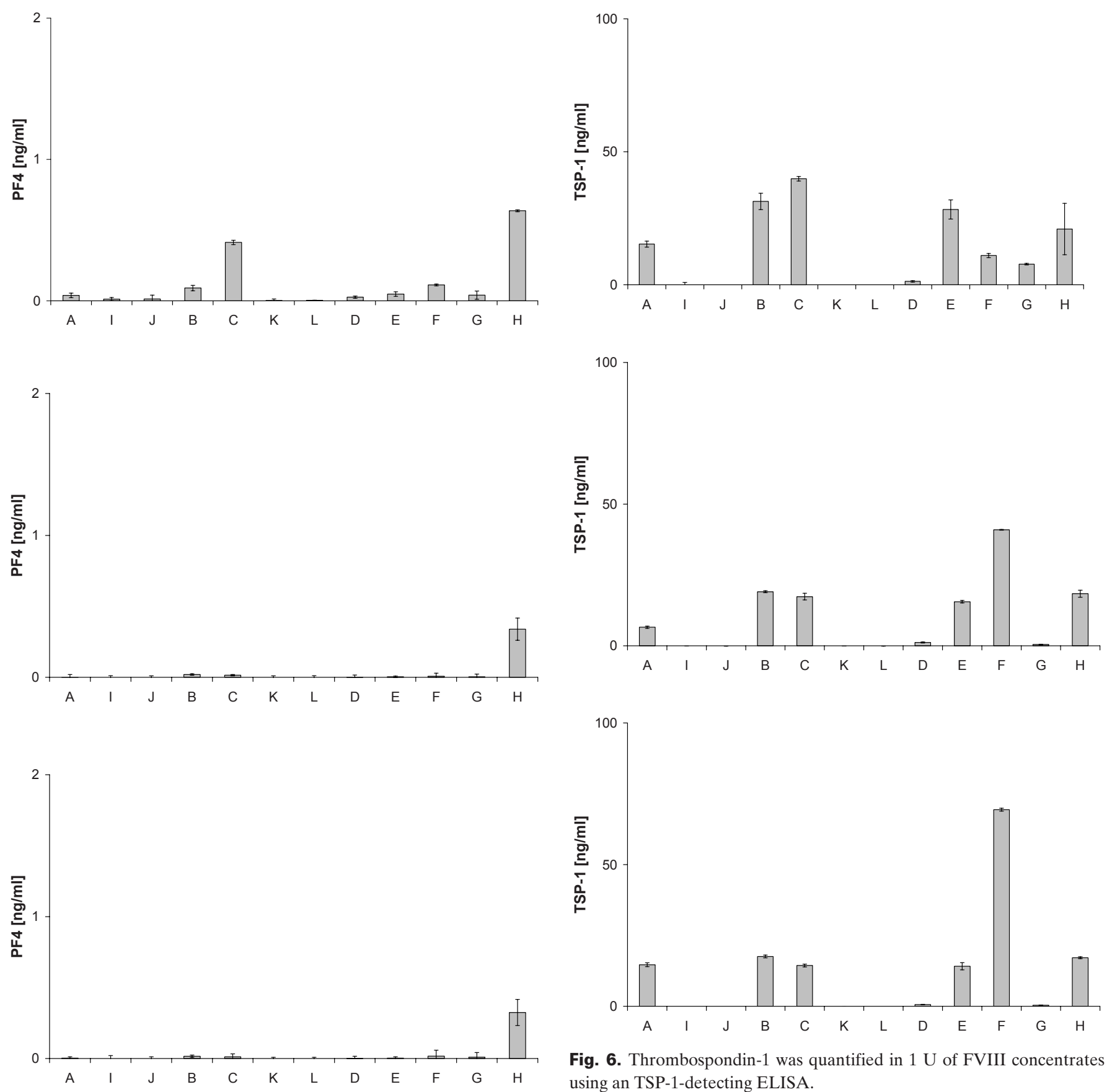

Fig. 6. Thrombospondin-1 was quantified in $1 \mathrm{U}$ of FVIII concentrates using an TSP-1-detecting ELISA.

A: Immunate STIM plus; B: Faktor VIII SDH Intersero; C: Haemoctin SDH; D: Fanhdi; E: Wilate; F: Beriate P; G: Haemate HS; H: Octanate; I: Advate; J: Helixate NexGen; K: KOGENATE Bayer; L: ReFacto.

A: Immunate STIM plus; B: Faktor VIII SDH Intersero; C: Haemoctin SDH; D: Fanhdi; E: Wilate; F: Beriate P; G: Haemate HS; H: Octanate; I: Advate; J: Helixate NexGen; K: KOGENATE Bayer; L: ReFacto.

(pH 3-10) and an SDS-PAGE using a 7.5\% polyacrylamide gel under reducing conditions to allow the FVIII-vWf complex to dissociate and the proteins to penetrate into the separating gel.

Figure 2 shows the 2D protein maps for the FVIII and vWf concentrates. All plasma-derived clotting factor preparations (A, B, C, D, E, F, G, H) showed protein spots compatible with

vWf. Protein spots compatible with albumin and fibrinogen were found for Haemate HS, Fanhdi, Immunate, Haemoctin SDH and Faktor VIII SDH Intersero. For Haemate HS and Fanhdi, the albumin spot was so prominent that the intensity of other protein spots in these preparations was low by comparison. Apart from these, all plasma-derived preparations contained other plasma proteins as impurities. Due to the high specific activity of the recombinant proteins, the amounts of protein in the gels were very low resulting in faint spots. 

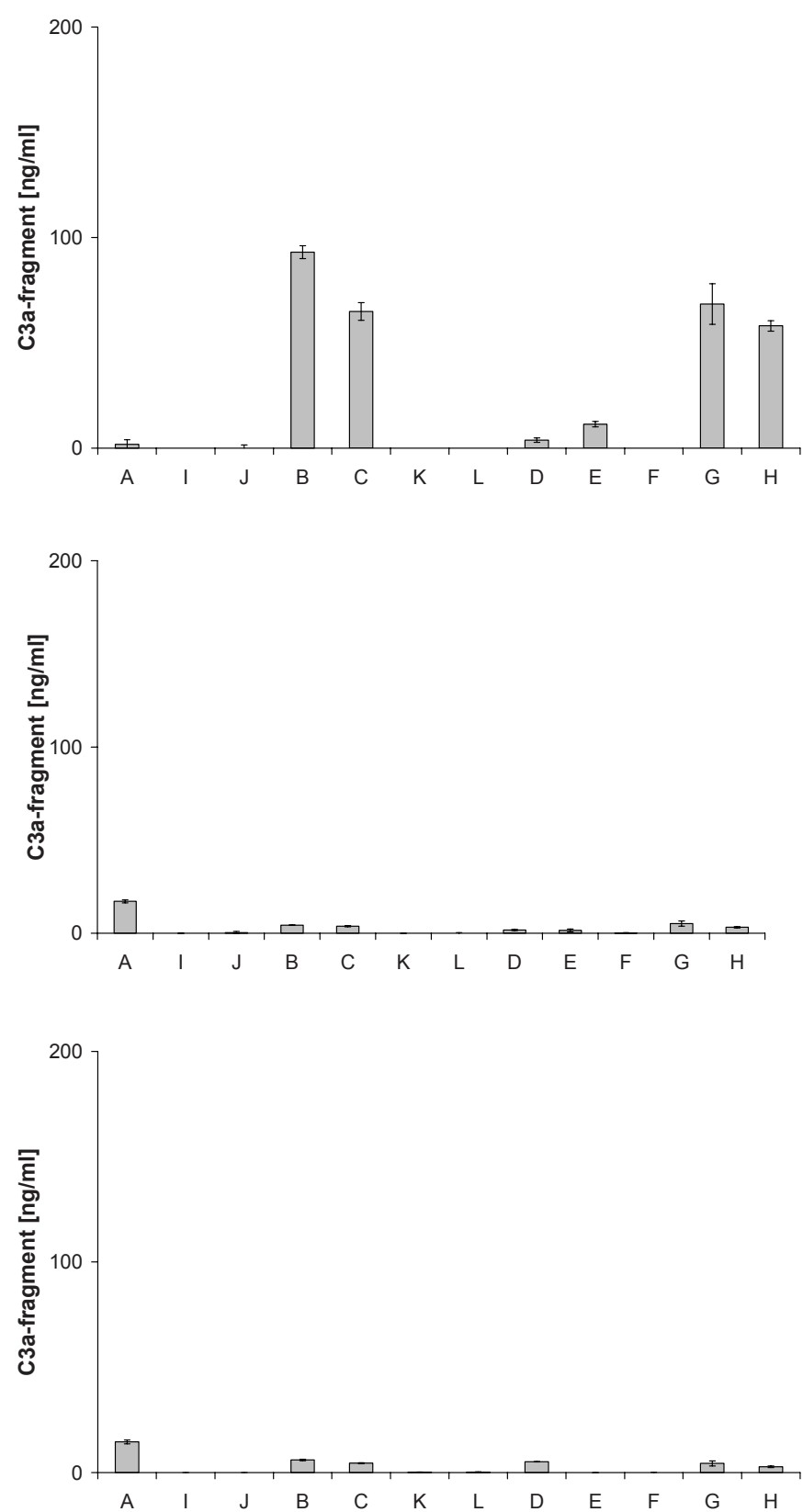

Fig. 7. Complement factor C3a was quantified in $1 \mathrm{U}$ of FVIII concentrates using an C3a-detecting ELISA .

A: Immunate STIM plus; B: Faktor VIII SDH Intersero; C: Haemoctin SDH; D: Fanhdi; E: Wilate; F: Beriate P; G: Haemate HS; H: Octanate; I: Advate; J: Helixate NexGen; K: KOGENATE Bayer; L: ReFacto.

\section{Cell Activation Markers}

2D-PAGE is not sensitive enough to detect rare proteins, and many proteins are not resolved. We therefore used ELISA to quantify contaminants of cell activation markers and complement activation polypeptides. We measured the amount of HNP 1-3 (fig. 3) and the enzyme myeloperoxidase (fig. 4) in the coagulation factor concentrates because these peptides were secreted by neutrophils when activated.

All batches of Immunate STIM plus, Faktor VIII SHD
Intersero, Haemoctin SDH and Octanate contained HNP 1-3, and concentrations of up to $0.05 \mathrm{ng} / \mathrm{IU}$ FVIII were found. Fanhdi, Wilate and Haemate HS all contained some HNP 1-3, but the amount of HNP 1-3 in Beriate $\mathrm{P}$ was below background level. No HNP 1-3 was found in the recombinant products.

Distinct inter-batch variability was observed for myeloperoxidase. All three batches from Faktor VIII SDH Intersero, Haemoctin SDH and Octanate contained myeloperoxidase, and up to $3.5 \mathrm{ng}$ myeloperoxidase/IU FVIII were found. Fanhdi contained no myeloperoxidase.

The findings for HNP 1-3 and myeloperoxidase suggested that it would be appropriate to look for platelet activation markers. When activated, platelets secrete PF-4 and TSP-1, the major secretion protein from their $\alpha$-granules. We therefore quantified the content of these two markers in the coagulation factor concentrates (fig. 5 and 6).

All batches of Octanate contained PF-4 (fig. 5). Up to 0.85 ng/IU of FVIII was detected. Traces of PF-4 were found in the batches of Faktor VIII SDH Intersero, Haemoctin SDH and Beriate P. No PF-4 was found in the recombinant FVIII products. TSP-1 was found in all tested batches of Immunate, Faktor VIII SDH Intersero, Haemoctin SDH, Wilate and Beriate $\mathrm{P}$ and in one tested batch of Haemate HS (fig. 6). The amount of TSP-1 was below background level in Fanhdi. No TSP-1 was found in the recombinant FVIII products.

\section{Complement Activation Markers}

Complement fragment C3a was measured as a marker of complement activation (fig. 7). There was distinct interbatch variability for $\mathrm{C} 3$ a content, but all three batches of Faktor VIII SDH Intersero, Haemoctin SDH, Haemate HS and Octanate contained C3a. The C3a concentration in FVIII concentrates was up to $90 \mathrm{ng} / \mathrm{IU}$ FVIII. No C3a was found in Beriate $\mathrm{P}$ or in the recombinant FVIII products.

\section{Discussion}

FVIII is a plasma protein essential for the blood clotting process. The human FVIII protein is composed of a light and a heavy chain and has a molecular weight of 280,000 Da. Its domain organization is typically described as A1-A2-B-A3C1-C2. ReFacto is a recombinant FVIII product in which the B-domain has been deleted to better stabilize the protein [6]. The single chain form of FVIII is readily proteolyzed in vivo and in vitro into multiple polypeptides with molecular weights ranging from 80,000 to 210,000 Da [7]. The main FVIII polypeptide band was found, as described by others [8], at an apparent molecular mass of 80,000 Da.

Because of the huge difference in specific FVIII activity we had found between the recombinant FVIII products $(4,000$ $14,000 \mathrm{IU} / \mathrm{mg}$ protein) and plasma-derived FVIII products (6-300 IU/mg protein), it was impossible to compare equal 
amounts of protein in the SDS gels. The total amount of protein in recombinant concentrates is very low. We therefore decided to separate 1 IU of the recombinant factor preparations in the $1 \mathrm{D}$ gels and $2 \mathrm{IU}$ in the $2 \mathrm{D}$ gels. It is unknown whether the high amount of foreign proteins infused with plasma-derived FVIII concentrates is a burden for patients with hemophilia [9].

In addition to FVIII proteins, the products we analyzed contained other proteins related to the purification and stabilization of FVIII. FVIII is an unstable protein, which is effectively stabilized in vivo by vWf. Most of the factor concentrates therefore contained $\mathrm{vWf}$, either from co-purification, as in all plasma-derived products, or as traces of recombinant vWf co-expressed in Chinese hamster ovary (CHO) cells, as in Advate. We found no vWf in KOGENATE Bayer, Helixate NexGen or ReFacto.

Immunate, Fanhdi and Haemate HS are stabilized by human albumin, as seen in the distinct bands in the 1D SDS gel (fig. 1a). All plasma-derived products contained some fibrinogen. Preparations of plasma-derived clotting FVIII are complex protein mixtures as demonstrated by the great number of protein spots in the 2D-PAGE gels. Clifton et al. [10] recently compared three plasma-derived FVIII-vWf concentrates (Octanate, Haemoctin and Wilate) and detected inter- $\alpha$-inhibitor proteins, fibrinogen and fibronectin in all three preparations as well as prothrombin in Octanate and Haemoctin.

The plasma used for FVIII concentrate preparations is derived from either source plasma or recovered plasma. Source plasma is collected in specialized plasma donation centers by plasmapheresis. Recovered plasma is collected from whole blood donations which are stored in blood bags for separation of cellular components for some hours. During the blood taking procedure, leukocyte depletion procedure or storage, the cellular components, the coagulation system or the complement system in the stored blood may be activated. Plasmapheresis techniques can also cause activation of platelets, complement and the coagulation process. The properties of the plasma are influenced by the time between blood donation and freezing of the plasma and whether the plasma is produced from whole blood or by plasmapheresis [11].

Runkel et al. [12] found significantly greater levels of prothrombin fragments 1 and 2, PF-4 and neutrophil elastase in recovered plasma than in apheresis plasma. Even the material of the inline filters used for leukoreduction of the whole blood influences the properties of the plasma. Charged filters have been shown to cause substantial complement activation [13, 14]. The quality of the final coagulation factor concentrates is very closely linked to the quality of the starting plasma. This is why we looked for markers of cell activation and of complement activation in the final products.

Human neutrophils contain large amounts of the host defense $\alpha$-defensin peptides HNP 1-3 [15]. They are secreted and released from PMNL granules upon activation. HNP 1-3 are small cysteine-rich cationic proteins that belong to the first line of defense against bacteria, fungi and many enveloped and non-enveloped viruses [16]. They trigger the release of TNF- $\alpha$ and IFN- $\gamma$ from the macrophages, which act in an autocrine loop to enhance expression of CD32 and CD64 and thereby enhance phagocytosis [17]. Current evidence also suggests an important immunomodulative role of these peptides $[18,19]$. It has been suggested that $\alpha$-defensins are potential mediators of inflammatory cardiovascular diseases. They have also been shown to contribute to endothelial dysfunction, lipid metabolism disorders and the inhibition of fibrinolysis [19]. Nassar et al. [20] described $\alpha$-defensins as risk factors for the presence and severity of arteriosclerosis, and as link between inflammation and arteriosclerosis. We have shown that human $\alpha$-defensins can induce platelet activation [21]. An increased level of $\alpha$-defensins was shown to be a blood marker for schizophrenia susceptibility [22]. These peptides have also been described as early markers for the development of colorectal adenomas and carcinomas, and it has been suggested that they might contribute to tumor growth [23].

In the present study, we found up to $0.05 \mathrm{ng} / \mathrm{IU}$ of $\mathrm{HNP}$ 1-3 in plasma-derived FVIII concentrates. It is unknown whether this amount is clinically relevant in hemophilia patients, but it clearly shows that the plasma used for fractionation contained proteins released by activated neutrophils.

A further marker of neutrophil activation confirmed this result. Myeloperoxidase is a key inflammatory enzyme released by human neutrophils, which can generate highly reactive oxygen species that cause additional damage in cerebral or myocardial ischemia [24, 25]. An emerging and significant body of research that suggests that myeloperoxidase may be a critical mediator in dysfunctional lipoprotein formation and therefore also in atherogenic initiation and progression [26-28].

We found up to $3.5 \mathrm{ng} / \mathrm{IU}$ myeloperoxidase in FVIII plasma concentrates. Interestingly, one product, Fanhdi, did not contain myeloperoxidase. This may be due to the purification procedure for this concentrate, which includes affinity chromatography on heparin. Because myeloperoxidase binds tightly to heparin [29], it may be separated from FVIII. As for $\alpha$-defensins, it is not kown whether the amount of myeloperoxidase in FVIII concentrates is clinically relevant, but myeloperoxidase is an active enzyme and there may be a cumulative effect over the time.

Activated leukocytes activate blood platelets and vice versa [30]. It is therefore not surprising that we found proteins from activated platelets in some FVIII concentrates, in addition to leukocyte activation markers.

The chemokine PF-4, also named CXCL-4, is a plateletspecific protein that is stored in platelet $\alpha$-granules and released following platelet activation. PF-4 has been reported to be involved in monocyte arrest on inflamed endothelium [31] 
and in monocyte differentiation to macrophages [32]. Woller et al. [33] showed that PF-4 stimulates monocytes to induce endothelial cell apoptosis by oxygen radical formation. In our study we found PF-4 in all three Octanate batches.

In addition to the platelet activation marker PF-4, we analyzed FVIII concentrates for the presence of TSP-1. TSP-1 belongs to the group of matricellular proteins, which are nonstructural extracellular matrix proteins that modulate cellmatrix interactions. TSP- 1 is the main $\alpha$-granule protein and is secreted upon platelet activation [34]. TSP-1 mediates platelet adhesion at high shear rates [35], promotes host cellular adherence of Gram-positive pathogens [35] and conveys cancer cell metastasis [36]. It is also involved in the process of apoptosis, or programmed cell death [37] and is a well-known extremely potent inhibitor of angiogenesis, effective at subnanomolar concentrations in vitro [38, 39].

Recent data suggest that TSP-1 is involved in the multimer size control of vWf [40], in smooth muscle cell regulation [41] and in vascular perfusion $[42,43]$. The TSP-1/TGF- $\beta / C T G F$ axis may contribute to the pro-inflammatory and pro-atherogenic state in rheumatoid arthritis sufferers [44]. TSP-1 has also been shown to induce dendritic cell immune tolerance [45] and might therefore influence antibody formation.

In the present study, all three batches of Immunate, Faktor VIII SDH Intersero, Haemoctin, Wilate and Beriate P contained TSP-1. The highest concentration was $40 \mathrm{ng} / \mathrm{IU}$. The clinical relevance of TSP-1 in FVIII concentrates used to treat hemophilia patients has so far not been investigated. The plasma-derived FVIII concentrate Fanhdi does not contain TSP-1. Like myeloperoxidase, TSP-1 binds strongly to heparin, and it is likely that in this product TSP-1 is removed by the heparin affinity chromatography used in the purification procedure.

Activation of platelets or contact with charged surfaces can activate the complement system. Complement activation has been described to occur in whole blood, plasma and filtered plasma during storage [46]. C3 is the most abundant protein of the complement system. Its cleavage product C3a, a 77amino acid peptide, plays a crucial role in the inflammatory response. It has been shown to induce smooth muscle cell contraction [47] and histamine release from mast cells [48] and basophil neutrophils [49], leading to increased permeability of the capillary beds. C3a is considered an anaphylatoxin [50] and acts as a cell activator with nanomolar affinity, exerting its functions through binding to its receptor $\mathrm{C} 3 \mathrm{aR}$. It is also involved in respiratory distress and asthma [51]. Recent studies suggest that, besides its host defense function, C3a contributes to pathological processes in inflammatory and im- munological diseases such as insulin resistance [52] as well as to adaptive immune response [53].

We observed high intra-product variability for C3a content. Up to $90 \mathrm{ng} / \mathrm{IU}$ of $\mathrm{C} 3 \mathrm{a}$ was detected in two batches of Immunate and in all three batches of Faktor VIII SDH Intersero, Haemoctin, Haemate HS and Octanate, but none was found in Beriate P. C3a was found in buffy coat-derived platelet concentrates in clearly higher concentrations than in apheresis-derived platelet concentrates [54]. It is therefore likely that recovered plasma contains more $\mathrm{C} 3 \mathrm{a}$ than apheresis plasma.

It is not known whether the activation markers that we had detected have a clinically relevant impact in hemophilia patients, but it has been shown in the past that the quality of the starting plasma used to produce the FVIII concentrate has a significant influence on its properties. Some batches of a plasma-derived, double-virus inactivated FVIII concentrate (marketed as Octavi SDPlus) that lead to a higher FVIII inhibitor formation were prepared from a starting plasma pools with elevated levels of coagulation markers [55]. Since activation of coagulation leads to activation of platelets and vice versa, it is likely that our batches of FVIII that contained cell activation markers were prepared from starting plasma with elevated levels of coagulation markers.

The concentrations of the impurities found in plasmaderived products were not high, but all substances found are pro-inflammatory. It is unknown whether the effect of these substances is additive and whether a lifelong contact with these activation products might have an influence on the health status of hemophilia patients. The rate of cardiovascular diseases in patients with hemophilia is lower than in agematched controls [56], but this is probably due to the low concentration of FVIII and the consequent low coagulation capacity of the blood. Hemophilia patients treated with products that do not contain pro-inflammatory byproducts might have even have lower rates of cardiovascular diseases. Further research into this is therefore necessary.

\section{Acknowledgement}

This work was supported by a grant of Bayer Vital GmbH, 51368 Leverkusen, Germany.

\section{Disclosure}

The authors declared no conflict of interest. 


\section{References}

1 Nilsson IM, Blomback M, Ramgren O: Hemophilia in Sweden. VI. Treatment of hemophilia A with the human antihemophilic factor preparation (fraction I-0). Acta Med Scand Suppl 1962;379:61-110.

2 Manco-Johnson MJ, Abshire TC, Shapiro AD, Riske B, Hacker MR, Kilcoyne R, Ingram JD, Manco-Johnson ML, Funk S, Jacobson L, Valentino LA, Hoots WK, Buchanan GR, DiMichele D, Recht M, Brown D, Leissinger C, Bleak S, Cohen A, Mathew P, Matsunaga A, Medeiros D, Nugent D, Thomas GA, Thompson AA, McRedmond K, Soucie JM, Austin H, Evatt BL: Prophylaxis versus episodic treatment to prevent joint disease in boys with severe hemophilia. N Engl J Med 2007; 357:535-544.

3 Blum H, Beier H, Gross HJ: Improved silver staining of plant proteins, RNA and DNA in polyacrylamide gels. Electrophoresis 1987;8:93-99.

4 Görg A, Obermaier C, Boguth G, Harder A, Scheibe B, Wildgruber R, Weiss W: The current state of two-dimensional electrophoresis with immobilized pH gradients. Electrophoresis 2000;21: 1037-1053.

5 Kehrel B, Balleisen L, Kokott R, Mesters R, Stenzinger W, Clemetson KJ, van de Loo J: Deficiency of intact thrombospondin and membrane glycoprotein Ia in platelets with defective collagen-induced aggregation and spontaneous loss of disorder. Blood 1988;71:1074-1078.

6 Neidhardt E, Koval R, Burke E, Warne N: In vitro evaluation of B-domain deleted recombinant factor VIII (ReFacto) stability during simulated continuous infusion administration. Hemophilia 2005; 11 : 319-325.

7 Pock K, Rizzi A, Josic D: Use of high-resolution techniques for the characterization of clotting factor VIII. J Chromatogr A 1999;852:175-188.

$\checkmark 8$ Kemball-Cook G, Bevan SA, Barrowcliffe TW Factor VIII heavy chain polypeptides in plasma and concentrates. Br J Haematol 1990;76:80-87.

$\checkmark 9$ Schulman S: Effects of factor VIII concentrates on the immune system in hemophilic patients. Ann Hematol 1991;63:145-151.

-10 Clifton JG, Huang F, Kovac S, Yang X, Hixson DC, Josic D: Proteomic characterization of plasmaderived clotting factor VIII-von Willebrand factor concentrates. Electrophoresis 2009;30:3636-3646.

11 Hellstern P: Fresh-frozen plasma, pathogen-reduced single-donor plasma or bio-pharmaceutical plasma? Transfus Apher Sci 2008;39:69-74.

12 Runkel S, Haubelt H, Hitzler W, Hellstern P: The quality of plasma collected by automated apheresis and of recovered plasma from leukodepleted whole blood. Transfusion 2005;45:427-432.

13 Runkel S, Bach J, Haubelt H, Anders C, Hitzler W, Hellstern P: The impact of two whole blood inline filters on markers of coagulation, complement and cell activation. Vox Sang 2005;88(1):17-21.

14 Cardigan R, Sutherland J, Garwood M, Krailadsiri P, Seghatchian J, Beard M, Beckman N, Williamson LM: The effect of leucocyte depletion on the quality of fresh-frozen plasma. Br J Haematol 2001;114:233-240.

15 Rehaume LM, Hancock RE: Neutrophil-derived defensins as modulators of innate immune function. Crit Rev Immunol 2008;28:185-200.

16 Bulet P, Stöcklin R, Menin L: Anti-microbial peptides: from invertebrates to vertebrates. Immunol Rev 2004;198:169-184.
17 Soehnlein O, Kai-Larsen Y, Frithiof R, Sorensen OE, Kenne E, Scharffetter-Kochanek K, Eriksson EE, Herwald H, Agerberth B, Lindbom L: Neutrophil primary granule proteins HBP and HNP1-3 boost bacterial phagocytosis by human and murine macrophages. J Clin Invest 2008;118:3491-3502.

18 Quinn K, Henriques M, Parker T, Slutsky AS, Zhang H: Human neutrophil peptides: a novel potential mediator of inflammatory cardiovascular diseases. Am J Physiol Heart Circ Physiol 2008;295: H1817-824.

19 Bowdish DM, Davidson DJ, Hancock RE: Immunomodulatory properties of defensins and cathelicidins. Curr Top Microbiol Immunol 2006;306:27-66.

20 Nassar H, Lavi E, Akkawi S, Bdeir K, Heyman SN, Raghunath PN, Tomaszewski J, Higazi AA: Alpha-defensin: link between inflammation and atherosclerosis. Atherosclerosis 2007;194:452-457.

21 Brodde MF, Vauthen H, Niemann S, Jurk K, Kehrel BE: Prothrombotic tendency upon inflammatory conditions - alpha defensins (HNP-1/2/3) are strong platelet agonists. J Thromb Haemost 2005;3(suppl 1):abstract OR016.

22 Craddock RM, Huang JT, Jackson E, Harris N, Torrey EF, Herberth M, Bahn S: Increased alphadefensins as a blood marker for schizophrenia susceptibility. Mol Cell Proteomics 2008;7:1204-1213.

23 Mothes H, Melle C, Ernst G, Kaufmann R, von Eggeling F, Settmacher U: Human neutrophil peptides 1-3 - early markers in development of colorectal adenomas and carcinomas. Dis Markers 2008;25:123-129.

24 Breckwoldt MO, Chen JW, Stangenberg L, Aikawa E, Rodriguez E, Qiu S, Moskowitz MA, Weissleder $\mathrm{R}$ : Tracking the inflammatory response in stroke in vivo by sensing the enzyme myeloperoxidase. Proc Natl Acad Sci U S A 2008 25;105:18584-18589.

25 Malle E, Furtmüller PG, Sattler W, Obinger C: Myeloperoxidase: a target for new drug development? Br J Pharmacol 2007;152:838-854

26 Sirpal S: Myeloperoxidase-mediated lipoprotein carbamylation as a mechanistic pathway for atherosclerotic vascular disease. Clin Sci (Lond) 2009;116: 681-695.

27 Wang Z, Nicholls SJ, Rodriguez ER, Kummu O, Hörkkö S, Barnard J, Reynolds WF, Topol EJ, DiDonato JA, Hazen SL: Protein carbamylation links inflammation, smoking, uremia and atherogenesis. Nat Med 2007;13:1176-1184

28 Nicholls SJ, Hazen SL: Myeloperoxidase, modified lipoproteins, and atherogenesis. J Lipid Res 2009;50(suppl):S346-351.

29 Baldus S, Rudolph V, Roiss M, Ito WD, Rudolph TK, Eiserich JP, Sydow K, Lau D, Szöcs K, Klinke A, Kubala L, Berglund L, Schrepfer S, Deuse T, Haddad M, Risius T, Klemm H, Reichenspurner HC, Meinertz T, Heitzer T: Heparins increase endothelial nitric oxide bioavailability by liberating vessel-immobilized myeloperoxidase. Circulation 2006;113:1871-1878.

30 Jurk K, Jahn UR, Van Aken H, Schriek C, Droste DW, Ritter MA, Bernd Ringelstein E, Kehrel BE: Platelets in patients with acute ischemic stroke are exhausted and refractory to thrombin, due to cleavage of the seven-transmembrane thrombin receptor (PAR-1). Thromb Haemost 2004;91:334344
1 Koenen RR, von Hundelshausen P, Nesmelova IV, Zernecke A, Liehn EA, Sarabi A, Kramp BK, Piccinini AM, Paludan SR, Kowalska MA, Kungl AJ, Hackeng TM, Mayo KH, Weber C: Disrupting functional interactions between platelet chemokines inhibits atherosclerosis in hyperlipidemic mice. Nat Med 2009;15:97-103.

32 Gleissner CA, von Hundelshausen P, Ley K: Platelet chemokines in vascular disease. Arterioscler Thromb Vasc Biol 2008;28:1920-1927.

33 Woller G, Brandt E, Mittelstädt J, Rybakowski C, Petersen F: Platelet factor 4/CXCL4-stimulated human monocytes induce apoptosis in endothelial cells by the release of oxygen radicals. J Leukoc Biol 2008;83:936-945.

34 Kehrel B, Flicker E, Wigbels B, Osterfeld M, van de Loo J, Lüscher EF: Thrombospondin measured in whole blood - an indicator of platelet activation. Blood Coagul Fibrinolysis 1996;7:202-205.

35 Jurk K, Clemetson KJ, de Groot PG, Brodde MF, Steiner M, Savion N, Varon D, Sixma JJ, Van Aken H, Kehrel BE: Thrombospondin-1 mediates platelet adhesion at high shear via glycoprotein $\mathrm{Ib}$ (GPIb): an alternative/backup mechanism to von Willebrand factor. FASEB J 2003;17:1490-1492.

36 Walz DA: Thrombospondin as a mediator of cancer cell adhesion in metastasis. Cancer Metastasis Rev 1992;11:313-324.

37 Li K, Yang M, Yuen PM, Chik KW, Li CK, Shing MM, Lam HK, Fok TF: Thrombospondin-1 induces apoptosis in primary leukemia and cell lines mediated by CD36 and caspase- 3 . Int J Mol Med 2003;12:995-1001.

38 Good DJ, Polverini PJ, Rastinejad F, Le Beau MM, Lemons RS, Frazier WA, Bouck NP: A tumor suppressor-dependent inhibitor of angiogenesis is immunologically and functionally indistinguishable from a fragment of thrombospondin Proc Natl Acad Sci U S A 1990;87:6624-6628.

-39 Tolsma SS, Stack MS, Bouck N: Lumen formation and other angiogenic activities of cultured capillary endothelial cells are inhibited by thrombospondin-1. Microvasc Res 1997;54:13-26.

40 Xie L, Chesterman CN, Hogg PJ: Control of von Willebrand factor multimer size by thrombospondin-1. J Exp Med 2001;193:1341-1349.

41 Patel MK, Lymn JS, Clunn GF, Hughes AD: Thrombospondin- 1 is a potent mitogen and chemoattractant for human vascular smooth muscle cells. Arterioscler Thromb Vasc Biol 1997;17:2107-2114.

42 Isenberg JS, Ridnour LA, Perruccio EM, Espey MG, Wink DA, Roberts DD: Thrombospondin-1 inhibits endothelial cell responses to nitric oxide in a cGMP-dependent manner. Proc Natl Acad Sci U S A 2005;102:13141-13146.

43 Isenberg JS, Martin-Manso G, Maxhimer JB, Roberts DD: Regulation of nitric oxide signalling by thrombospondin 1: implications for anti-angiogenic therapies. Nat Rev Cancer 2009;9:182-194.

44 Rico MC, Rough JJ, Del Carpio-Cano FE, Kunapuli SP, Dela Cadena RA: The axis of thrombospondin-1, transforming growth factor beta and connective tissue growth factor: an emerging therapeutic target in rheumatoid arthritis. Curr Vasc Pharmacol 2010;8:338-343.

45 Krispin A, Bledi Y, Atallah M, Trahtemberg U, Verbovetski I, Nahari E, Zelig O, Linial M, Mevorach D: Apoptotic cell thrombospondin-1 and heparin-binding domain lead to dendritic-cell phagocytic and tolerizing states. Blood 2006;108: 3580-3589. 
46 Hyllner M, Tylman M, Bengtson JP, Rydberg L, Bengtsson A: Complement activation in prestorage leucocyte-filtered plasma. Transfus Med 2004;14 $45-52$

47 Drouin SM, Kildsgaard J, Haviland J, Zabner J, Jia HP, McCray PB Jr, Tack BF, Wetsel RA: Expression of the complement anaphylatoxin $\mathrm{C} 3 \mathrm{a}$ and C5a receptors on bronchial epithelial and smooth muscle cells in models of sepsis and asthma. J Immunol 2001;166:2025-2032.

48 el-Lati SG, Dahinden CA, Church MK: Complement peptides $\mathrm{C} 3 \mathrm{a}-$ and $\mathrm{C} 5 \mathrm{a}$-induced mediator release from dissociated human skin mast cells. J Invest Dermatol 1994;102:803-806.

49 Glovsky MM, Hugli TE, Ishizaka T, Lichtenstein LM, Erickson BW: Anaphylatoxin-induced histamine release with human leukocytes: studies of C3a leukocyte binding and histamine release. J Clin Invest 1979;64:804-811.
50 Haas PJ, van Strijp J: Anaphylatoxins: their role in bacterial infection and inflammation. Immunol Res 2007;37:161-175.

51 Humbles AA, Lu B, Nilsson CA, Lilly C, Israel E, Fujiwara Y, Gerard NP, Gerard C: A role for the $\mathrm{C} 3 \mathrm{a}$ anaphylatoxin receptor in the effector phase of asthma. Nature 2000;406:998-1001.

52 Mamane Y, Chung Chan C, Lavallee G, Morin N, Xu LJ, Huang J, Gordon R, Thomas W, Lamb J, Schadt EE, Kennedy BP, Mancini JA: The C3a anaphylatoxin receptor is a key mediator of insulin resistance and functions by modulating adipose tissue macrophage infiltration and activation. Diabetes 2009;58:2006-2017.

53 Peng Q, Li K, Sacks SH, Zhou W: The role of anaphylatoxins $\mathrm{C} 3 \mathrm{a}$ and $\mathrm{C} 5 \mathrm{a}$ in regulating innate and adaptive immune responses. Inflamm Allergy Drug Targets 2009;8:236-246.
54 Böck M, Rahrig S, Kunz D, Lutze G, Heim MU Platelet concentrates derived from buffy coat and apheresis: biochemical and functional differences. Transfus Med 2002:12:317-324

55 Josić D, Buchacher A, Kannicht C, Lim YP, Löster $\mathrm{K}$, Pock K, Robinson S, Schwinn H, Stadler M Degradation products of factor VIII which can lead to increased immunogenicity. Vox Sang 1999; 77(suppl 1):90-99.

56 Siboni SM, Mannucci PM, Gringeri A, Franchini M, Tagliaferri A, Ferretti M, Tradati FC, Santagostino E, von Mackensen S; Italian Association of Hemophilia Centres (AICE): Health status and quality of life of elderly persons with severe hemophilia born before the advent of modern replacement therapy. J Thromb Haemost 2009;7:780-786. 